\title{
Community transformation through the Pentecostal churches
}

\begin{tabular}{|c|c|}
\hline \multicolumn{2}{|c|}{$\begin{array}{l}\text { Authors: } \\
\text { Njabulo Tfwala }^{1} \\
\text { Maake Masango }^{1}\end{array}$} \\
\hline \multicolumn{2}{|c|}{$\begin{array}{l}\text { Affiliations: } \\
{ }^{1} \text { Practical Theology } \\
\text { Department, University of } \\
\text { Pretoria, South Africa }\end{array}$} \\
\hline \multicolumn{2}{|c|}{$\begin{array}{l}\text { Project leader: } \\
\text { Maake Masango } \\
\text { Project number: } 02467526\end{array}$} \\
\hline \multicolumn{2}{|c|}{$\begin{array}{l}\text { Description: } \\
\text { This research is part of the } \\
\text { research project, 'Pastoral } \\
\text { Care and Trauma } \\
\text { Counselling', directed by } \\
\text { Prof. Dr Maake Masango, } \\
\text { Department of Practical } \\
\text { Theology, Faculty of } \\
\text { Theology, University of } \\
\text { Pretoria. }\end{array}$} \\
\hline \multicolumn{2}{|c|}{$\begin{array}{l}\text { Corresponding author: } \\
\text { Maake Masango, } \\
\text { maake.masango@up.ac.za }\end{array}$} \\
\hline \multicolumn{2}{|c|}{$\begin{array}{l}\text { Dates: } \\
\text { Received: } 14 \text { July } 2016 \\
\text { Accepted: } 27 \text { Sept. } 2016 \\
\text { Published: } 02 \text { Dec. } 2016\end{array}$} \\
\hline \multicolumn{2}{|c|}{$\begin{array}{l}\text { How to cite this article: } \\
\text { Tfwala, N. \& Masango, M., } \\
\text { 2016, 'Community } \\
\text { transformation through the } \\
\text { Pentecostal churches', HTS } \\
\text { Teologiese Studies/ } \\
\text { Theological Studies 72(3), } \\
\text { a3749. http://dx.doi. } \\
\text { org/10.4102/hts.v72i3.3749 }\end{array}$} \\
\hline \multicolumn{2}{|c|}{$\begin{array}{l}\text { Copyright: } \\
\text { (C) 2016. The Authors. } \\
\text { Licensee: AOSIS. This work } \\
\text { is licensed under the } \\
\text { Creative Commons } \\
\text { Attribution License. }\end{array}$} \\
\hline \multicolumn{2}{|c|}{ Read online: } \\
\hline 口:pris & $\begin{array}{l}\text { Scan this } Q R \\
\text { code with your } \\
\text { smart phone or } \\
\text { mobile device } \\
\text { to read online. }\end{array}$ \\
\hline
\end{tabular}

This article constitutes an attempt at reflecting on the extent Pentecostal churches in Swaziland are transforming their communities towards God's justice mandate. The article shows that liberation has not yet gone beyond the split between socio-political engagement and spiritual enrichment in the liturgy for the Pentecostal churches in Swaziland, such that the fruit of liturgy is not lived out in the community, including polity and the judicial order. A transformative liberative pastoral care methodology is purposed for this article.

\section{Introduction}

In one of the chiefdoms, KaLuhleko, a group of women paraded their buttocks at the gates of the umphakatsi [chiefdom] to express their dissatisfaction with the way they were being governed. This was their form of protest action. In African-Swazi culture it is lichilo [an outrage] for a woman to show her backside to the elders of the community. As a result, the women were arrested and charged with public indecency, according to the Swazi Observer of 7 March 2016.

Some of the Christian women lamented that they missed such a parade because they were religious and could not participate in protest action involving exposure of their bodies. However, it is a fact that what bothers the community also concerns Christians by virtue of being members of society. Mbiti confirms, 'it takes the whole village to raise a child' (1990:80). Hence it is the responsibility of everyone who lives to care for the other people in the community.

On the same note, some houses at KaNgcamphalala Chiefdom were burnt down on allegations of community governance disputes. In the Sunday Observer, 7 February 2016, the Indvuna [chief's forerunner] was overheard asking for prayers of protection for the chiefdoms. Indeed requests, prayers, intercession and thanksgiving must be made for everyone - for kings and all those in authority - that we may live peaceful and quiet lives in all godliness and holiness (1 Tim 2:1-2 NIV). In addition to prayers, churches have been observed giving food and clothing to these affected areas.

While it is important to offer relief in the short term, there must also be concerted efforts to transform those structures. Such stories, as portrayed in media daily, challenge the church to consistently evaluate their core mission statement if they are to effectively address holistically human predicaments. Hence the question is, to what extent do the Swaziland Pentecostal churches' teachings influence and guide the Swazi community to just and peaceful dialogues?

This quest is driven by the fact that 'the church is there' in every community. The church will remain there, long after foreign peace organisations have gone home, and thus the church maintains a sustainable position. The church's ministers carry authority with the Swazi people in a way that distant political leaders never can. Thus, King Mswati III in his speech at the opening of Parliament on 12 February 2016 called for dialogue and peace as a medium of conflict resolution and management in the country. The church must be at the forefront in making sure that justice is practised for all so that the country can experience peace.

\section{An understanding of Swazi politics}

Swaziland is an exception to the fate of most African kings, about whom Mbiti states: 'the office of the traditional monarch is losing its sacredness, and seems to be degenerating to the inevitable point of being a political anachronism and an economic debit' (1969:186). For Swaziland, since the days of King Sobhuza II, the Swaziland monarchy appears to have been gaining momentum. The legacy of King Sobhuza II lives on to this day. He was the brains behind the banning of political parties in Swaziland and no one in political leadership would dare change that position. Of course 
with the present constitution, parties are provisioned, though this has not yet been implemented in practice.

In terms of the 2005 Constitution, Section 64 (1), the executive authority of the country is vested in the king as head of state. Next to the Ingwenyama [king] is the Ndlovukazi [queen mother]. The chairman of cabinet and leader of government is the prime minister. However, Section 64(3) of the constitution gives the king the right to delegate his powers to either minister. This concentrating of powers to the king filters down to those below the king, the prime minister being the case in point for the modern system of government and chiefs for the traditional system of government. The prime minster appoints a cabinet minister on behalf of the king.

The traditional system of governance is run at Tinkhundla centres by chiefs who report to the king. Chiefs rule communities on behalf of the king. The challenge comes when chiefs are in dispute with their subjects. According to Swazi culture, the elders are always right, as the king is 'umlumo longacali manga' [the king's word is final]. Danger in abuse of power is dividing communities as chiefs may abuse the king's authority for their benefit. Therefore, the church has to come in reconciliatory mode with an understanding of the dynamics of Swazi politics. Debly states that, 'it is a mistake to ignore or undermine the political strength of the African people' (2011:21). Thus, partnerships or work relationships should be an articulation of values that promote a more authentic ethic of community leaders and church relationships. The Pentecostal churches' discourse should encourage their incarnational approach within the Swazi traditional system of governance, which is pivotal to encourage engagement in community disputes.

\section{Swaziland Pentecostal churches' liturgy and community transformation}

Note that there are problems in defining the Pentecostal churches' liturgy due to the doctrinally and structurally heterogeneous nature of classical Pentecostal churches in Swaziland. Generally, what unifies the many denominations and independent groups forming classical Pentecostalism is the common experience of baptism in the Holy Spirit rather than confessions. Nel confirms that 'confessions play a rather insignificant role amongst Pentecostals for whom the charismatic experience of the guidance of the Spirit is imperative' (2007:525). However, the Swaziland Pentecostal churches are governed under the Swaziland Conference of Churches (SCC). The SCC brings together Evangelical, Pentecostal and Charismatic churches. Other Christian organisations have their affiliation on the basis of the common confession of their Christian faith with the SCC (SCC 2015 Constitution: Article-Basis of Unity). It is imperative to note that Pentecostal churches have their denominational constitutions; however for membership it is a prerequisite that member constitutions harmonise with the SCC constitution as the governing body.
To this effect, the SCC constitution (2015) reveals that the mission of the church is to preach the Good News:

We are witnesses of Christ. We publicly state our Christian beliefs for the purpose of winning others to Christ. We carry and deliver the Gospel daily, corporately and individually and make disciples as provided in the Bible. Evangelism is carried mostly through National Crusades and Prayers. (SCC Constitution, Article 10:1)

Spiritual empowerment within believers is as observed during vibrant services in the form of dancing, shouting and speaking in tongues. Phiri confirms that, 'Pentecostal churches seem to be convinced that the task of the church is primarily spiritual' (2012:7). Freston notes, in support:

... the driving force behind one of the largest Pentecostal churches - Yong Cho's ministry from the beginning, however, has been such as the work of the Holy Spirit to save souls and empower the growth of the Church to the ends of the earth. (2000:217)

This means that spirituality in Pentecostal churches in Swaziland has not gone beyond merging socio-political engagement and spiritual enrichment in the liturgy. Prayer is therefore the method through which Pentecostal churches engage in priestly ministry on behalf of the nation. Preaching is at large on salvation from sin is their prophetic ministry. Are prayers and national crusades enough to embrace righteousness and justice in order to criticise oppressive and violent acts against the Swazi people as experienced between chiefs and their subjects? As a practical theologian of the Pentecostal church my argument is therefore, if and when Pentecostals are selective in addressing issues that rob individuals and communities of their dignity, is their vision and calling practically addressing the plight of human injustice? Are Pentecostal churches' teachings cultivating among all the people of Swaziland the fundamental human rights of peace, freedom of expression and dignity of the human person? This article argues that preaching and prayers are not enough to address human predicaments. What about those who do not come to church? Opportunities do not always allow for church attendance. In such cases media could be used for the benefit of the voiceless. Thus addressing community disputes in public would not give an impression of the church having a dichotomous ministry (e.g. spiritual and material). However, 'spiritual ministry' means that the social, political and economic ministries are part of the spiritual, not a separate entity.

According to the constitution of Swaziland (Chapter 3, Section 24): 'A person has a right to freedom of thought, conscience and religion'. Therefore, freedom of speech and expression must be taken as considerations of public defence, safety, public order, public morality, public health and the rights and freedoms of persons pursuing to voice their concerns by the Pentecostal churches. Hence, it should be noted that human rights and missions should be treated as one mission. Gerkin notes that, 'to address human experiences holistically is important in that it helps the pastoral caregiver to have as his starting point. That is, he or she begins where 
the people are' (1997:13). It is necessary to add that we attend to the living human spiritual documents not only as separate, but as entrenched with the socio-economic and political structures. Prior (1995) observes that:

if spiritual empowerment is understood in light of Jesus' Spiritempowered works of liberation as in the gospel of Luke-Acts, then a Liberative theology of the political also becomes a possibility. (p. 18)

Therefore, Pentecostal churches must go beyond focusing on healings, the miraculous and charismatic manifestations of the spirit and see how these phenomena may also function as signs of the spirit's praxis in our communities. Buffel correctly points out that pastoral care cannot afford to remain aloof from the socio-economic and political realities present in all our societies (2007:178). Hence, the challenges experienced in our communities allow no room for a superficial quick fix; problems must be dealt with in consideration of the political dimensions of life as experienced by God's people.

\section{The need for a liberative transformative Pentecostal theological discourse}

The African church, in particular Pentecostal churches, is finding itself in the middle of political dynamics that have an effect on its ministry focus. This study observes the need for transformative theological discourses. Anderson and Kerr define 'transformational change' as follows:

... a process whereby an old state of affairs and world-view are forced to die. In most cases, the new state is not yet known; it emerges from trial-error and thus learning takes place. (2002:22)

Theologically we speak of a New Jerusalem (Rev 21). In support of Anderson and Kerr, Van Klinken shares that it is important to question the direction of any transformation' (2010:3).

For this study, this change is a positive deconstruction and reconstruction of Pentecostal churches' discourse such that they embrace the contemporary concept of life-giving in a world reeling from the effects of injustice and violence. The process is 'positive' because this deconstruction is done in a positive way - in order to replace it with something better. Pollard observes that, 'there are none of the negative connotations that are sometimes associated with the branch of literary criticism known as deconstruction, but rather a positive search for truth' (1997:44).

Pollard follows a narrative model that is favoured amongst practical theologians because it rests upon shared ideas, concepts and field observations. Winter and Hawthorne admit that, 'stories can be used to argue a point, interject humour, illustrate a key insight, comfort a despondent friend and challenge an opinion' (1999:405). Hence, getting engaged with community stories could help pastoral caregivers connect to the imaginations and emotions of citizens suffering from violations of their freedom of speech. Pentecostals therefore should embrace the need to transform their spiritual focus to include addressing people's socio-political issues, including community disputes.

This will require a fundamental shift in the Pentecostal churches' belief about their communities' public engagements. This is a critical area that this transformation has to take into account in terms of the Pentecostal churches' participation in community disputes.

Therefore, an enormous task for Pentecostal churches is to transform their theological perceptions and the Pentecostal traditions that influence their participation in political issues. These are related to the human experiences that lead to liberating actions, which portray the holistic redemptive work of Christ, who died for all.

Buffel notes that, 'the strength of liberation theology chiefly lies in its methodology' (2007:197). Thus, this study proposes a liberation theology that supports liberation from the Western concepts of individualistic worship to the AfricanSwazi communal context. Buthelezi (1978), an African liberation scholar, observes two different approaches to African liberative theology: the anthropological approach and the ethnographic approach. The study is interested in both of them as they are contextual to the expectations of this article.

\section{The African liberative approach}

According to Buthelezi, when we speak of an 'anthropological' approach we are thinking of a person not as an object of study, but as a creature of God who was entrusted with 'dominion' over the rest of creation (1978:65). Buthelezi maintains that ' $t]$ heology in Africa must reflect the throbbing of the life situation in which people find themselves' (1978:65). This article agrees with Buthelezi that theology must continually wrestle with the evils of today's socio-political order so that people may enjoy the dominion that has been liberated by Christ from all that dehumanises. These encompass both individual and constitutional evils. Hence, Pentecostals cannot afford to remain aloof from the present political realities in our societies, especially those that are characterised by the marginalisation of Swazi citizens through land grabbing and violence against freedom of speech and print rights, as evidenced in the introduction.

\section{Buthelezi notes that:}

the ethnographic takes as its point of departure the traditional, African cultural worldview. Its goal is to translate the Christian faith into an African context, to retrieve Africa's past, to make Christianity indigenous. (1978:56-76)

In a homogenous society like Swaziland, where everyone is related to everyone else, it cannot be expected that anyone can be a Swazi and not be related to the king and the Swazi traditions. Swazis are a homogenous people - one tribe, one language. Each person is dependent on the other. Hence, a 
practical implementation of the reconstructed values of partnership praxis in Christian relationships is vital.

The Swaziland Pentecostal churches need to transform the Western individualistic focus of independent ministry to communal attention. Most Pentecostal churches are pioneered by individual ministers and end up being independent ministries instead of a communal body of believers, as recorded in 1 Corinthians 12 . The challenge is when the financial resources are controlled by the leader. This creates room for self-centeredness and neglect of other believers and societal needs. Thus with many Pentecostal churches, when there are no policies to govern the church, the pastor, apostle, prophet or bishop as a founder becomes the final authority. Thus, for Pentecostal churches an ethnographic position could be a transformation of individualistic-oriented ministry leadership to a protestant leadership focus. Our general observation is that the individualistic ministry focus disadvantages Pentecostal churches, keeping them from being better positioned to challenge unbiblical cultural practices as one voice. Hence, the church loses its position of being the conscience of the people. Only as Pentecostals transform from a Western individualistic faith into a Swazi communal context will they achieve their full liberation.

This liberation will enable them, through the interpretation and application of the Bible, to realise that politics is from God and not some demonic influence, as commonly termed. In support Chitando notes, '[o]ne of the most significant aspects of the Christian heritage in Africa has been the centrality of the Bible' (2006:6). In support of Chitando, Mbiti (1990:247) writes: 'Africa is deeply immersed in the Bible'. This study agrees with the two gurus of African theology that before foreign missionaries came to Africa, Africans already had an idea of God. Mbiti observes, however, that 'they used the names of the God who was and is already known by African people such as Mungu, Mulungu, Katonda, Mvelinchanti and thousands more' (1981:55). Thus, this study deems it fit to create an understanding of God within the Swazi people that would engage the story of God, which is embraced with practical love and coupled with justice, not just scientific facts about God. It is of utmost importance that Pentecostal theology follow the African liberation theologians who have travelled in their critique of academically bound religion in order to liberate theology. This liberation is so that it can act within the context of a real world scarred by sin and injustice.

\section{Wimberly observes that:}

what is needed is a holistic approach involving preaching, pastoral care, and participation in church life that has some potential to change the shame based narratives that undergird people's lives. (1999:18)

This portrays the need for the proposed framework that focuses on the concept of 'positive deconstruction' as emphasised in chapter 3 .
Christ's mission statement, as declared in a Nazareth synagogue and recorded in Luke 4 , is the mainstay in understanding and in shaping Pentecostals' ideology towards their participation in Swazi politics. Stearns writes, 'the Luke passage was the culmination and fulfilment of more than twenty centuries of God speaking to the nation of Israel through Moses and the prophets' (2010:53-54). In this Lukan discourse the great themes of reconciliation, compassion and justice are woven deeply throughout both the Old and New Testaments. This is the vacuum that the study sees within the Pentecostal churches' emphasis on their sermons as evidenced by their 2005 constitution and the reviewed literature (Anderson 2004; Nel 2007).

\section{Mentoring process}

In line with transformative actions, a mentoring process that aims to help Pentecostals journey with Swazi people, who are marginalised by their communities, Wimberly's approach on 'Nurturing the Alleviated Individuals By Their Communities' (2000), will be adopted for this article. Wimberly addresses the issue of alienated individuals as being among the root causes of social problems, such as violence, domestic strife, racial prejudice and addiction. He calls such individuals 'relational refugees'. 'Relational refugees are persons not grounded in nurturing and liberating relationships, thus treated as outcasts on their home land' (2000:20). Hence, the story of the women not allowed opportunities to voice their concerns about the way they are marginalised by their chiefdom and communities who end up burning the chiefdoms are examples of freedom of 'alienated refugees' citizens treated as refugees in their home country.

This is a call for pastoral caregivers to reconsider sacrificing their luxurious lifestyles for the sake of the community. Not that we are jealous of their blessings, but we believe that God blesses for the benefit of sharing with the needy. Gerkin observes that, 'a shepherd puts his life in danger for the sake of the sheep' (1997:10). Pentecostal pastors should be like the shepherd of old - David, who fought against the predator that wanted to devour his father's sheep. This is a concern of the study, as he looks at sheep scattered without shepherds. Sheep are likened to Swazi citizens, whose basic rights were violated for staying in the land they were given by their forefathers.

\section{Relationship between Christianity and the state}

The connection between the state and Christianity in Swaziland is the culmination of Somhlolo's dream for the country (Kasenene 1999; Kumalo 2013; Ndlovu 1994).

\section{King Somhlolo's dream}

Somhlolo's dream has had a great influence on Christianity becoming one with the state. In a nutshell:

In a dream King Somhlolo saw white-skinned people carrying two objects: a scroll (umculu) and a round object (indilinga). 
The king was instructed in the dream to advise the Swazi people to do three things. Firstly, the white skinned people were not to be hurt in any way. Secondly, the scroll was to be accepted. Lastly, the round object was to be rejected and take the scroll Bible. (Matsebula 1988:41)

In the Swazi context, the dream is believed to have come to the king from divine origins. Thus, Christianity in this context also originated from the Swazi traditional religion - Incwala. However, the interpretation of Somhloloism has of course been the subject of debate led by Swazi theologians, which is still open to accurate research. However, conservative Evangelical or Pentecostal theologians have made the bold assertion that 'Christ revealed himself to King Somhlolo in a vision' (UNISWA 1990:29).

Time and time again Christianity and government intersect appropriately and necessarily so in Swaziland. Through taxes, the government provides subsidies to religious-based hospitals, nursing homes, child and family service agencies, relief agencies, homeless shelters, spousal abuse homes and many more.

The church - in particular Pentecostal churches - complements the state in the provision of social services. The church has built valuable church institutions such as hospitals, schools and universities. In this regard, Green's (2006) warning of recent perspectives on the interfaces between religion and state in Africa is crucial. She comments that 'Africans quest for literacy through mission education eventually brought materialism in the education system which eventually moved out the spiritual mandate' (2006:640). As the author pursues Green's warning, a suggestion is that the church lobby for moral values in government schools as they are enforced in their missionary schools. Englund supports the view that 'such a position could brand the church to "practical moral purposes" such that students are informed in their particular circumstances to be morally upright' (2007:7). Therefore, Pentecostal churches are strategically placed to make a difference in the context of the socio-political lives of the Swazi people. Such a context calls for an understanding of Swazi politics.

On the negative side, we observe that the incarnation of the church with the state compromises the community justice mandate of the church, in particular the Pentecostal churches. Such a position is detrimental to the church as the conscience of the people. As the king and iNgwenyama is the head of the nation and government, he is also the head of the religious faction (The Constitution of The Kingdom of Swaziland 2005: Section V11, Article 64). For instance, with the League of African Churches - Traditional Swazi Churches upon the demise of a church leader, the succeeding leader is brought to the king to bless the ordination. Hence, challenging inconsistencies in behaviour within the government could be viewed as challenging the king, which is disrespectful to the authorities of the land.

Debly observes that the intertwining of religion, culture and politics has a significant influence on Swazi politics (2011:48). She maintains that the marriage between the church and the state reinforces the status quo (2011:48). The state-religion model is founded on an alliance between the state and a specific religion or particular religious tradition. In this model, the state uses its power to promote Swazi traditional religions and customs at the expense of the church. Thus, the ecumenical church is not convincingly engaged with fighting injustice in the communities. This article supports the idea that the intertwining of royalty and Christianity compromises the debate on the justice mandate from the church side. Thus, we suggest a transformed position for the church and state relationship enabling legitimate freedom of speech rights for all Swazis. Swazis honour their traditional beliefs, wherein every Swazi citizen is encouraged to participate. Pentecostals have been observed to hold a non-participatory mode towards Swazi traditional practices.

\section{Pentecostal churches' non- participatory mode towards Swazi traditional religions}

Pentecostal churches' participation in traditional religious celebrations such as Incwala [First-Fruit Celebration] is at stake. The sacred Incwala ceremony, celebrated around December in mid-summer, is a dominant national ceremony celebrated when a king is on the throne. In religious terminology, it is often regarded as a sacred national prayer ceremony, as it has a significant meaning to an ordinary Swazi. However, further studies are recommended for biblical approval. The religious freedom language of Pentecostal churches means that the church must be kept in a separate sphere from 'evil worship', to the extent this is possible. The common scripture used is: 'Do not be unequally yoked together with unbelievers ... And what communion has light with darkness? And what accord has Christ with Belial?' (11 Cor 6:14 NIV). However, a misappropriation of this scripture could disadvantage the church's influence as light and salt of the world (Mat5:13-16). Therefore, an accommodative approach that encompasses an understanding of the moral dilemma of Swazi traditional religions must be adopted for the relevance of the Pentecostal churches in their communities.

\section{Moral dilemma of Swazi traditional religions}

Cultural symbols like the Incwala ceremony that unite the nation are commonly described as 'national prayer'. The people eagerly support any move, whether political or spiritual, that unites them. Indeed, praying together, the people are united in one spirit. Pentecostals should learn to tolerate people of other religions, not only the few former adherents with whom they are acquainted as 'saved ones'. Likewise, if there is any evil that is observed in traditional religious practice it should be challenged with respect.

\section{The Prophet Nathan's approach to King David (2 Sam 12:1-14)}

David's sins of adultery, cold-blooded murder and its subsequent cover-up were exceptional evil in God's sight. He became guilty of breaking the sixth, seventh, eighth, ninth 
and tenth commandments (Ex 20:13-17). Matthews (2006) comments that it should have followed that the Lord sent enemies to invade him. Instead, he sent a prophet to him Nathan, his faithful friend and confidant - to instruct and counsel him.

With this kind of respect shown by the prophet Nathan to his authority, the king had to confess. He says not a word to excuse himself or extenuate his sin but freely owns up to it: 'I have sinned against the Lord' (v. 13). This approach could work well with the Pentecostal churches' relationship with Swazi politics. As the king is the head of the nation and leads communities through the chiefs, so maintaining good working relationships with the chiefdoms is paramount for churches. When one criticises a chief, it could be mistaken as an attack on royalty. Thus, preachers are caught in between politics and Christianity in Swaziland. Therefore, partaking in traditional ceremonies like Incwala should be taken as incarnational missiology. Hence, to underestimate the impact and significance of the Incwala ceremony and ancestral veneration in the religious life and spirituality of the church would be to commit a great blunder as it does have a bearing on Swazis' understanding of what God (Mvelinchanti) expects of them, as revealed in Somhlolo's dream.

Ndlovu, commenting on the moral controversy on the Incwala ceremony among religious groups notes:

The main sacred indigenous ceremony that dramatizes and embodies the key symbols of Swazi culture, are namely, the monarchy, the ancestral religion, and indigenous regiments. The basic intent of the Incwala is to affirm the king as a primary symbol of Swazi culture and society. Hence one of the significant rites at the Incwala is the ritual cleansing, purification and strengthening of the king who is the symbol of the Swazi Nation. (Report on the Ecumenical Seminar on Swazi Culture 1994:22)

Other African writers on African religions support African traditional religion. Therefore, Pentecostals must reconsider their missiology impact in relation to Swazi religions.

Asamoah-Gyadu, in support of African religions, notes:

It could not have been the African people who coined the phrase 'ancestor-worship' because they do not believe that ancestors can be worshipped at all. It must have been in someone's interest to demonise African culture and religion in order to promote that which appealed to him or her. In the African religious practice ancestors are serviced not worshipped, thus Africans talk of (umsebenzi kaBaba/uMama) commemoration function for passed parents. (2006:5)

Thus, the church in particular should make a distinction between worship and the veneration of ancestors. Not all Swazis worship their ancestors, but most of them venerate them. This calls for further studies of Swazi traditional religions and worship or veneration of ancestors.

In contrast, community leaders should recognise that the church has a God-given mandate to guide the spiritual and social lives of the nation. Paul concluded all of his letters with a list of practical duties that were based on the doctrines he had discussed (Rom 13). In the Christian life, doctrine and duty always go together. What we believe helps to determine how we behave. It is not enough for us to understand Paul's doctrinal explanations. We must translate our learning into living and show by our daily lives that we trust God's word.

Competing with the incarnational position is the churches' confrontational position.

\section{A confrontational approach to community disputes}

Community dispute confrontations have to include both self-determination and self-affirmation (Monsma in Gushee 2000:199). This means that the confrontational pole is against political structures taking advantage of or disadvantaging any citizen's particular religious stand (Gushee 2000:199). The underlying principle is equal treatment of people in their homeland. This is in line with the Swaziland Constitution 2005:

all persons are equal before and under the law in all spheres of political, economic, social and cultural life and in every other respect and shall enjoy equal protection of the law. (Chapter 111, Article 20)

Only with this position will full freedom of participation for justice prevail.

\section{Pentecostal self-determination}

Pentecostals' beliefs must be announced to the nation and they must point out where the existing traditional religious order at any time is in conflict with them. If there are aspects of demonic worship in traditional religious observances, such as the Incwala ceremony, the church may have the spiritual power to replace that demonic worship with Godly worship. In just the same way, the church may not tell a politician what ends the political order should promote but must leave it to the politician to devise the precise means to those ends.

This principle was applied by Paul when evangelising in Athens:

${ }^{22} \mathrm{Paul}$ then stood up in the meeting of the Areopagus and said: 'Men of Athens! I see that in every way you are very religious. ${ }^{23}$ For as I walked around and looked carefully at your objects of worship, I even found an altar with this inscription: TO AN UNKNOWN GOD. Now what you worship as something unknown I am going to proclaim to you'. (NIV, Ac 17:22-25)

Paul did not accuse the Athenians of worshipping 'false gods'. However, he introduced the unknown God to them in a loving and respectful manner. This is how the gospel should be preached - recognition of others' beliefs first, followed by taking them from the known to the unknown. Secondly, they must then pass on to Christian citizens, acting in their civic capacity, the task of reshaping the existing order in closer conformity with the principles. For at this point technical 
knowledge may be required and judgments of practical expediency are always required.

In contrast, self-affirmation sets the church apart as the conscience of the nation. This is when the transcendent holiness of the church is used to reshape the politically unjust systems of this world by providing an ethical and prophetic critique of the present unjust practices. This is the position the Jews took while in bondage in the Persian kingdom:

Then Haman said to King Xerxes, There is a certain people dispersed and scattered among the peoples in all the provinces of your kingdom whose customs are different from those of all other people and who do not obey the king's laws; it is not in the king's best interest to tolerate them. (NIV, Es 3:8)

Haman was correct when he described the Jews as a people whose 'laws are different from those of all other people' (Es 3:8). Their laws were different because they were God's chosen people who alone received God's holy law from his own hand. Moses asked, ' $[a]$ nd what great nation is there that has such statutes and righteous judgments as are in all this law which I set before you this day?' (Deut 4:8, NKJV) and the answer is: 'None!' (Matthews Commentary 2006). This is the position the Pentecostal churches should be showing towards the state religions.

The only group that seems to understand the position that the church has to be the conscience of the state is the SCC and its affiliates, who are very vocal on human rights issues. It is very clear from the scriptures that Christians cannot be neutral on the matter of human dignity, freedom and equality, in realising the importance the Bible attaches to freedom, human dignity, equality and justice (Gen 1:26). This article recommends that Swazi Pentecostal churches grapple with the challenge of fear, uncertainty and the embrace of syncretism arising from allegiance to the closely intertwined Swazi culture and traditional religion. This dilemma has been observed to lead many professed Christians to remaining traditionalists at heart and to the tendency for Christianity to become an alien religion to traditional Swazis. Therefore, discovering who we are as Pentecostal Christians is an invitation to the churches for deep spirituality rooted in the incarnation model of other religions. This involves a quest to study more about African religions like Incwala and to actively discern God's divine will in other worship styles and objects.

When we decide to tolerate an action or a practice, we decide to forego an opportunity to interfere in some instance with that activity or practice (Powell \& Clarke 2001:3). Powell and Clarke note that there are two dimensions in 'tolerance', namely those who argue for tolerance of particular acts and practices and those that suggest the 'principle of harm' as a guide to the possible limits of tolerance (Powell \& Clarke 2001:4, 6).

Therefore, religious practices that involve unjustified harm to others should not be tolerated. Of course, the challenge is what exactly constitutes 'harm' and what counts as 'unjustified'. This is a matter of dispute with religious groups and in particular Pentecostal Christianity. However, the harm principle is a plausible starting point for the delineation of the limits of incarnation for liberals (Powell \& Clarke 2001). Thus the church has to uphold their position of being the light of the world.

\section{Pentecostal self-affirmation}

The church still has to stand on the principle of being the light and salt of the land - to be in the world but not of the world (Jn 17:14b). The church, in particular the Pentecostal churches, must be positioned to affirm its own cultural heritage, in this case Pentecostal heritage (Gushee 2000). The constitution of the Kingdom of Swaziland has paved the way for:

freedom of expression, which includes the freedom of the press and other media, that is to say ... freedom to communicate ideas and information without interference and freedom from interference with the correspondence of that person. (Chapter 3, Section 24 [2])

Thus, one of the major roles of Pentecostal churches is to preserve the historic reservoirs of Pentecostal culture on resistance to injustice and the independence of Pentecostalism as evidenced by the acts of the early church apostles. This theological position derives from the experience that characterised the outpouring of the Holy Spirit in the Book of Acts, particularly Acts 2 . Nel argues that, 'in fact one cannot talk about Pentecostals without relating it, first and foremost to the events that unveiled in the book of Acts as the roots of Pentecostalism' (2007:527). Hence, self-affirmation also means Pentecostal churches' transformation from Western Pentecostal churches to Swazi Pentecostalism. AsamoahGyadu argues that, 'there is no doubt that African traditional religious practice has been exploited and deliberately misconstrued so as to promote Western religious practice' (2006:5). Asamoah-Gyadu (2006) also maintains that:

if they were to promote their value system they had to undermine local experience and lift the Western value system which is based on individual ethic such as the emphasis on celibacy being superior to marriage. (p. 6)

Hence, this has become one of the strong detachments of Pentecostals and Swazi traditional religious practices.

In reality, Pentecostals have to look at parallels in these religious practices, using common ground for the foundation of a more constructive approach to evangelism. King Sobhuza 11 used to say that Swazis must copy what is good from foreign cultures and leave the bad. Likewise Pentecostal churches must embrace the good from the culture and leave what contradicts with scripture. This spirituality of discernment and action is based on a hermeneutic that exposes the limitations of human structures and points to God's deep love of humanity revealed in our Lord Jesus Christ. It is when we appreciate this deep love of God for humanity that all human relationships rediscover their reconciliatory moral basis. 


\section{Reconciliatory approach to community disputes}

Pentecostal churches should be the main mediating and socialising vehicle in community disputes by questioning why citizens are treated as aliens in their homeland, in addition to the church taking an inclusive evangelism approach while maintaining an exclusive holiness separation role.

Africans and Swazis are known to put emphasis on negotiations, which develop from a unified culture of respect. Unfortunately bit by bit we are losing our African-Swazi inheritance of buntfu whereby we openly talk about our grievances. Thus, we observe continuous struggles within our communities and government levels on issues of fair economic distribution, including the definition of property rights. The church (in particular the Pentecostal churches) has a pivotal role in the revitalisation of the values of buntfu, such as morality, respect of human dignity, humanness, compassion, care and understanding. Ubuntu means 'seeking grace and mercy for others'.

\section{One fundamental political response is of grace and mercy}

This position is when an atmosphere whereby people can speak authentically about their illness whether spiritual, physical, political and social needs. The opening statement of the preamble of the 2005 constitution of the Kingdom of Swaziland reads as follows:

Whereas We the People of the Kingdom of Swaziland do hereby undertake in humble submission to Almighty God to start afresh under a new framework of constitutional dispensation. (Opening statement of 2005 Constitution of Kingdom of Swaziland)

In embracing our constitution as EmaSwati we see ourselves as members of the same family of God. Thus, it is clear that respect of human dignity is a central element with Swazis, hence the popular Siswati greeting 'Sanibonani boNkhosi', meaning that all Swazis are Dlamini (one nation-one language). Dlamini is popular, as the king's surname is Dlamini. Hence, if you do not know a person's particular surname you address that person as 'Dlamini'.

As stated earlier, gradually we are losing our Siswati inheritance of buntfu whereby we openly talk about our grievances. Thus, we observe continuous struggle between government and civil servants on issues of fair economic distribution including the definition of property rights. The church has a pivotal role in the revitalisation of values of buntfu - morality, respect of human dignity, humanness, compassion, care and understanding.

The church is at community level and it commands much respect from its members and the public. Echoing the biblical prophets, Christ showed a particular concern for the poor, the weak and the marginalised (Mt 25). Jesus could have taken up arms with the Romans and led a violent political revolution to secure the kind of worldly kingship hoped for by the Jewish people suffering under the yoke of Rome. Instead, while being arrested for treason, Jesus told Peter to drop his sword and said, "Those who use the sword will die by sword' (Mt 26:52 NLT).

When a forum for open dialogues is not available, people tend to confront and attack.

Violence in most cases has less good results. People are both predictable and unpredictable. In Brent's words, this is an apocalyptic approach as it reflects the struggle with the power structures of contemporary society. Thus great Babylon was to be annihilated in a disaster.

If there is such a thing as freedom of expression, press and worship as dictated by the constitution of the Kingdom of Swaziland, Chapter III, Section 25, we must expect to be surprised now and again by human behaviour, as evidenced by the women parading near the chief's compound as a method of voicing their grievances. If people are not allowed to voice their concerns, they opt for destructive means. Jesus was prepared to face a closer engagement with contemporary Graeco-Roman imperial culture, which was in compromise with justice for all (Lk 4:16-19). We believe that through this method the alienation and crucifixion of innocent individuals as exemplified by our introduction will be minimised and never duplicated.

\section{Conclusion}

Because the well-being of the people rests largely on governance of the people whether at local, national, or international level (Yong 2010:3), the Pentecostal churches' discourse cannot afford to be separated from the sociopolitical challenges linked to the socio-economic issues of the country. This article has described the theological underpinnings that make Pentecostal churches take only trivial or no cognisance of the challenging political issues facing Swaziland. Pentecostals primarily attend to spiritual needs, which overshadow their socio-political ministry. This article has determined that a transformative mode against the neutral position is key to the Pentecostal churches lobbying against unjust practices of the Swazi communities. Church ministers carry authority with the Swazi people in a way that distant political leaders never can.

\section{Acknowledgements Competing interests}

The authors declare that they have no financial or personal relationships that may have inappropriately influenced them in writing this article.

\section{Authors' contributions}

Both N.T. and M.M. contributed equally to this article. 


\section{References}

Anderson, A., 2004, An introduction to Pentecostalism: Global Charismatic Christianity, Cambridge University Press, Cambridge, UK.

Anderson, K. \& Kerr, C., 2002, Customer relationship management, McGraw Hill, New York.

Asamoah-Gyadu, J.K., 2006, Encountering Jesus in African Christianity: A Ghanaian Evangelical/Pentecostal thought on faith, experience, and hope in Christ, (Trinity Theological Seminary, Legon, Accra, Ghana. Research Associate: Department of Church History), University of Pretoria, Pretoria.

Buffel, O.A., 2007, Pastoral care in a context of poverty: A search for a pastoral care model that is contextual and liberating, University of Pretoria, Pretoria.

Buthelezi, M., 1978, 'Towards indigenous theology in South Africa'. The emergent Gospel: Theology from the underside of history, Sergio Torres and Virginia Fabella, Orbis Books, Maryknoll, NY.

Chitando, E., 2006, Living with hope. African churches and HIV/AIDS1. WCC Publications, Geneva.

Debly, T.M., 2011, Culture and Resistance: Swaziland 1960-2011, University of New Brunswick, New Brunswick, NJ.

Englund, H., 2007, 'Christian independency and global membership: Pentecostal extraversions in Malawi', Journal of Religion in Africa 33(1), 83-111. http://dx.doi. org/10.1163/157006603765626721

Freston, P., 2000, Evangelicals and politics in Asia, Africa, and Latin America, Cambridge University Press, Cambridge.

Gerkin, C.V., 1997, An introduction to pastoral care, Abingdon Press, Nashville, TN.

Green, M., 2006, Priests, witches and power: Popular Christianity after mission in Southern Tanzania, Cambridge University Press, Cambridge.

Gushee, D.P., 2000, Christians \& politics beyond the culture wars. An agenda for engagement, Baker Book House, Grand Rapids, MI.

Kasenene, P., 1999, Swazi traditional religion and society, Webster's Publishing Company, Mbababne.

Kumalo, R.S., 2013, Religion \& politics in Swaziland: The contributions of Dr. J.B. Mzizi, Sun MeDIA Bloemfontein under the SUN PRESS Imprint.

Masango, M.J., 2000, 'Pastoral theology in the African contexts', in I.A. Phiri \& D. Werner (eds.), Handbook of theological education in Africa, pp. 744-755, Regnum Books International, Oxford.

Matthew Henry's Commentary on the Whole Bible, 2006, PC Study Bible, Olive Tree Bible Software, viewed n.d., from https://www.olivetree.com/store/product. php?productid $=16623$

Matsebula, J.S.M., 1988, A History of Swaziland, 3rd edn., Longman, Cape Town.

Mbiti, J., 1969, African religions and philosophy, Praeger, New York.

Mbiti, J., 1981, The encounter of Christian faith and African religion, Crossroad, New York.
Mbiti, J., 1990, The Bible theology in African Christianity, Oxford University Press, Nairobi.

Mugambi, J.N.K., 1989, An African Christian theology: An introduction, East African Educational Publishers, Nairobi.

Ndlovu, H.L., 1994, Report on the ecumenical seminar on Swazi culture, Unpublished article.

Ndlovu, H.L., 2011, The Swazi Monarch. Its Religio-cultural genius, Unpublished article.

Nel, M., 2007, Pentecostals reading of the Old Testament, North West University, Mahikeng.

Phiri, E.F., 2012, A survey of social involvement by the Pentecostal Assemblies of God (Zambia), University of South Africa, Pretoria.

Pollard, N., 1997, Evangelism made slightly less difficult, Inter-Varsity Press, Downers Grove, IL.

Powell, R. \& Clarke, S., 2001, Religion, tolerance and intolerance: Views from across the disciplines, Oxford University, Oxford.

Prior, M., 1995, Jesus the liberator: Nazareth liberation theology. The Biblical seminar, Sheffield Academic Press, Sheffield, UK.

Stearns, R., 2010, The hole in the Gospel, Thomas Nelson, Nashville, TN.

Swaziland Government, 1994, Report on the Ecumenical Seminar on Swazi Culture, Swaziland Government.

Swaziland Government, 2013, Report on International Religious Freedom in Swaziland Swaziland Government Statistics.

Sunday Observer 07, February 2016, viewed n.d., from http://www.observer.org.sz

The Constitution of the Swaziland Conference of Churches, 2005, SCC draft reviewed constitution, Swaziland Kingdom, Swaziland.

The Swaziland Government, 2005, The Constitution of the Kingdom of Swaziland Act, Swaziland Kingdom, Swaziland.

UNISWA, 1990, Report on the First National Seminar for a Relevant Theology for Swaziland, UNISWA.

Van Klinken, A.S., 2010, 'Theology, gender ideology and masculinity politics: A discussion on the transformation of masculinities as envisioned by African theologians and a local Pentecostal Church', Journal of Theology in Southern Africa 138, 2-18.

Wimberly, E.P., 1999, Moving from Shame to self-worth, Abingdon Press, Nashville. Wimberly, E.P., 2000, Relational refugees, Abingdon Press, Nashville.

Winter, R.D. \& Hawthorne, S.C., 1999, Perspectives on the world Christian movement, William Carey Library, Pasedena, CA.

Yong, A., 2010, In the days of Caesar. Pentecostalism and political theology, Library of Congress Cataloguing in Publication Data, Eerdmans Publishing Co, Grand Rapids, MI. 